\title{
Att lyssna till en kör av röster: \\ Den berättarfokuserade intervjun
}

\section{MARGARETA HYDÉN}

Omvi forskare $i$ socialt arbete vill lyssna till människors berättelser om erfarenheter som tidigare inte uttryckts, utan snarare aktivt undertryckts, hur skall vi då gå till väga? Om vi vill förhålla oss öppet till en komplex och pluralistisk förståelse av kön, vilka konsekvenser bör det få för vår metod? I artikeln presenteras en intervjumetod som har vuxit fram ur ett behov av finna svar på dessa frågor. Den är särskilt utformad med tanke på studier om känsliga ämnen.

Att anlägga ett könsperspektiv på ett fenomen eller ett ämne betyder, enkelt uttryckt, att rikta intresse mot den form och funktion genus har i det aktuella sammanhanget. När det gäller ämnet socialt arbete har könsperspektiv i praktiken kommit att bli liktydigt med kvinnoperspektiv. Endast undantagsvis har män och manlighet blivit föremål för studier, och när så skett har det varit någon form av "problematisk manlighet" som undersökts. Exempel på sådana studier är

Margareta Hydén är docent i socialt arbete och leg. Psykoterapeut. Hon är verksam vid institutionen för socialt arbete, Stockholms Universitet. Hennes forskningsområden omfattar våld mot kvinnor, familjeforskning, samt narrativ forskningsmetod.
Sven-Axel Månssons och Annulla Linders (1984) undersökning av manliga prostitutionskunder, Sven-Axel Månssons undersökning av invandrade mäns problem i mötet med svensk sex- och samlevnadskultur (1984), samt min egen studie (Hydén 1995) av män som misshandlar kvinnor i nära relationer. Studier som skulle kunna ge intressant kunskap om män i socialt arbete men som än så länge saknas, är exempelvis sådana som undersöker i vilken utsträckning mäns erfarenheter kommer till uttryck inom en kvinnodominerad verksamhet som socialt arbete.

Med ett kvinnoperspektiv som utgångspunkt har flera olika slag av studier kommit till stånd. Socialt arbete har dragit nytta av 
de grundläggande feministiska studier som riktat kritik mot könsblindhet inom samhällsvetenskapen. Könsneutralitet kan ge legitimitet åt kvinnoförtryck genom att män görs till norm och kvinnors erfarenhet marginaliseras (Holter 1970, Haavind 1973). Studier har ägnats problemformulering och definition av sociala problem, med utgångspunkt från dess speciella betydelse för kvinnors välfärd och välbefinnande (Dominelli och McLeod 1989; Meltzer Olsson 1994). En kategori undersökningar har handlat om att synliggöra gruppen kvinnor och flickor bland socialvårdens klienter. Exempel på sådana undersökningar är Evy Gunnarssons (1993) studie av ensamstående kvinnliga socialhjälpstagare och Astrid Schlytters (1999) undersökning om tvångsvård av unga flickor. En grupp studier har handlat om att lyfta fram kvinnors livssitution, som i Maren Baks (1997) studie av ensamstående mödrar och Martha Szebehelys (1995) arbete om kvinnor som arbetstagare i hemtjänsten.

En central aspekt av feministisk kunskap är att betrakta kvinnan som ett kunskapsbärande subjekt. Genom historien har kvinnor förvägrats tillgång till berättelsen om sin egen erfarenhet, på sätt som för många visat sig destruktivt och skadligt för hälsan. Deras berättande har tystats, eller inte kunnat utvecklats därför att ingen velat lyssna. I synnerhet gäller detta erfarenheter som har att göra med våldshandlingar utförda av män, från sexuella övergrepp till misshandel. Att lyssna till dessa berättelser, få dem nedskrivna och analysera dem, hör till kvinnoforskningens viktigaste uppgifter.

\section{Vad är en "kvinna»}

Under det senaste decenniet har den feministiska analys som ställt existensen av ett kvinnoperspektiv i motsättning till ett mansperspektiv genomgått en grundlig omprövning. Den normativa enhetligheten i diskursen om kvinnor har ifrågasatts i formuleringar som: kan man verkligen tala om ett kvinnoperspektiv? Existerar verkligen "kvinnan« i bestämd form singularis? Afroamerikanska feministiska forskare som bel hooks (1984) och Patricia Hill Collins (1990) har framfört kritik mot att feministisk forskning och teoribildning i regel utgår ifrån västerländska, vita heterosexuella kvinnor från medelklassmiljöer och låter dem utgöra Den Kvinnliga Röst som vi skall lyssna till. Postmodernister som Judith Butler (1990) och Linda Nicholson (1989) hävdar att enhetliga uppfattningar om en kvinnoidentitet måste ersättas av mer pluralistiska och komplexa uppfattningar om social identitet, i vilken kön utgör en viktig identitetskälla, men så även klass, etnisk tillhörighet, ålder och sexuell läggning. En motsvarande diskussion förekommer inom mansforskningen, där forskare som Robert Connell (1995) hävdat, att "man» inte är något som låter sig definieras utifrån ett enda perspektiv. Förståelsen av "man« kan utgå från ett biologiskt perspektiv, men att tro att män och manlighet kan förstås enbart som biologi vore att missförstå relationen mellan kropp och sociala processer, menar Connell. Maskulinitet måste förstås i relation till femininitet, samt i sitt historiska- och politiska sammanhang (a.a. s.44).

Den feministiskt skolade forskare som lärde sig att lyssna uppmärksamt och meto- 
diskt till kvinnans röst, samt arbetade med att utveckla en analysapparat som gjorde det möjligt att beskriva världen ur ett kvinnoperspektiv, befinner sig i en problematisk situation idag. "Feminist Standpoint Theory“ (Hartsock 1983; Harding 1991), en gång så betydelsefull för feministisk teoriutveckling, har kritiserats och beskrivits som en relik från feminismens mindre sofistikerade förgångna. Att skriva in »Kvinnans» erfarenhet i samhällsvetenskapen (Smith 1987), den uppgift som för 25 år sedan tycktes så angelägen och befriande, kan nu förefalla förtryckande på sitt eget paradoxala sätt, eller i alla fall alltför normativt anspråksfull. Det sena 90-talets kvinnoforskning förefaller ha avvikt från den dikotoma verklighetens diskurs. Intresset riktas nu inte enbart mot likhet, mot det som förenar kvinnor som kvinnor, utan också mot skillnad, mot konstruktion och dekonstruktion av »kvinnlighet«. Det betyder inte att det moderna projektet är övergivet och att vi fullt ut befinner oss i en postmodern tidsålder. Tvärtemot pågår en livaktig debatt mellan företrädare för dessa två traditioner. Hill Collins arbete om black feminist thought (1990) utgör en av hörnstenarna i den "the third wave feminism" som beskrivits som det senaste tillskottet i en utveckling inom feministisk teoribildning och som bygger på skillnad som tema (Lengermann \& Niebrugge-Brantely 1996).

\section{Att lyssna till en kör av röster}

Det är mot bakgrund av denna diskussion som min artikel skall ses. Det utgör ett försök att svara på frågor som: om vi forskare i socialt arbete vill lyssna till kvinnors och mäns berättelser om erfarenheter som tidigare inte uttryckts, utan snarare aktivt undertryckts, hur skall vi då gå till väga? Om vi dessutom vill förhålla oss öppet till en komplex och pluralistisk förståelse av »kvinnan" och "mannen", vilka konsekvenser får det för vår metedologiska ansats? Jag vill försöka besvara dessa frågor genom att presentera den intervjuform jag utvecklat under arbetet med två studier om mäns våld mot kvinnor i nära relationer (se fotnot 1 och 2 i slutet av artikeln för en beskrivning av dessa).

Mitt kunskapsintresse i dessa studier har varit något annorlunda än det inom kvinnoforskning gängse. Jag har främst varit intresserad av att utforska händelsen mäns våld mot kvinnor i nära relationer, inte hur män som grupp förtrycker kvinnor som grupp. Jag har velat undersöka hur de inblandade talar om denna händelse - men det är inte de kommunikativa aspekterna $i$ sig som fångat mitt intresse. Det är sättet att beskri$v a$ vad som hänt och vilka omständigheter som åberopas i mäns och kvinnors beskrivningar av våldshändelser vars förövare respektive offer de själva varit, som jag velat utforska. Mitt intresse för dessa framställningar har dock begränsat sig till ett intresse för de konsekvenser av upplevelsen av våldet som är språkligt burna. Jag har frågat mig sådant som: vad betyder det för henne när hon beskriver det som hänt i termer av ett „bråk»? När hon i stället talar om »misshandel«, på vilket sätt förändras hennes upplevelse? När han menar att det varit ett »bråk» och hon att det var frågan om "misshandel", vad betyder det för deras äktenskap? När han insisterar att han "glömt» vad han gjor- 
de, men tydligt kan dra sig till minnes att hon "provocerat»? Vad innebär det för parternas upplevelse av händelsen, av sig själva, av äktenskapet? Samtliga dessa frågor handlar om hur våldshändelsen tolkas av berörda parter. Det vill säga, det handlar om en process av meningsskapande som $i$ allt väsentligt - om än ej uteslutande - är buren av språket. Ordet "bråk" respektive ordet "misshandel" placerar våldshändelser i två helt olika kategorier, med två helt olika upplevelser av händelsen som konsekvens. I detta kunskapssökande har intervjun varit mitt främsta redskap.

Sedan jag planlade min första studie i mitten av 1980-talet har mycket förändrats i synen på vad en intervju är och vilken slags kunskap som är lämplig att söka med hjälp av intervju som metod. Intresset av att förstå intervjuns karaktär av samspel mellan människor har ökat, i takt med att synen på att forskarens uppgift består av att presentera objektiva fakta ifrågasatts (se exempelvis Mishler 1986). I denna diskussion har interaktionen mellan intervjuare och intervjuperson kommit i fokus. Föreställningen att det är möjligt för forskaren att upprätthålla en utanförposition i förhållande till det som studeras, har utmanats. Intervjun har kommit att betraktas som en samproduktion mellan intervjuare och intervjuad. Bland feministiska forskare har det pågått en liknande diskussion, i vilken forskningens reflexiva egenskaper lyfts fram. Det som betonats är vikten av att se forskaren som en del av det som studeras, och inte betrakta henne som en åskådare (se exempelvis Wilkinson 1988; Riessman 1997).

Det som skiljer olika intervjuformer åt kan vara graden av struktur, men även de element som strukturerar intervjun. De flesta intervjuformer använder antingen frågorna eller svaren som strukturerande element. Hög grad av struktur innebär att frågorna är formulerade i förväg och svarsalternativen är fasta, låg grad av struktur innebär ett mer öppet samtal där forskningsfrågorna står i centrum, men utan bundna svarsalternativ. Frågorna är inte ordagrant formulerade i förväg, utan det finns utrymme för infall och avvikelser. Den form av intervju som framför allt beskrivits och analyserats i den digra litteratur som publicerats inom kvinnoforskning och annan samhällsvetenskaplig forskning under senare tid, är den halvstrukturerade intervjun som utgår från vissa teman, men tillåter ett fritt talande om dessa teman. Intervjun äger rum vid ett tillfälle och berör sådant som tidigare har hänt ( Banister et al. 1994; Gergen \& Davis 1997; Mishler 1986; Sherman \& Reid 1994; Smith, Harré \& Van Langenhove 1995; Reinharz 1992). Syfte med detta intervjuarbete är att få en bild av informantens uppfattning, upplevelse eller utsaga i ett givet ämne. Det är däremot mer ovanligt att metodlitteraturen beskriver en öppen intervju, som äger rum vid upprepade tillfällen och som undersöker något som pågår. Ett viktigt undantag är de feministiska forskarna Patti Lather och Chris Smithies (1997), som i sin studie av HIV- positiva kvinnor följt 25 kvinnor under två år, för att genom öppna intervjuer följa den process kvinnorna gick igenom.

Den intervjuform jag utvecklat och vill beskriva, bygger vare sig på frågor eller svar som grundläggande strukturerande element. Den fokuserar den intervjuade, och är uppbyggd i syfte att underlätta och stödja 
hans eller hennes fria berättande. Den är särskilt utformad med tanke på studier av känsliga ämnen och pågående processer. Målet med intervjun är att möjliggöra för den intervjuade att formulera sig i en så fullödig och mångfacetterad berättelse som möjligt. Den tes jag försöker driva i artikeln är att forskarens förmåga att skapa en relation till den intervjuade är av central betydelse för om detta mål kommer att uppnås eller ej. Vad jag hoppas kunna visa är att denna förmåga utmanas vid varje intervjutillfälle, liksom forskarens förmåga att kunna använda relationen till den intervjuade på ett kreativt sätt. Tre aspekter av intervjuarbete är grundläggande i min framställning. Den första är intervjuns interaktiva aspekt. Den uttrycker att forskningsintervjun bäst låter sig beskrivas som ett samtal mellan en eller flera människor. Liksom alla samtal är forskningsintervjun en samarbetsprocess där språket används för att skapa mening i sitt speciella sammanhang. Den andra aspekten är intervjuns polyfona aspekt. Den belyser den intervjuades olika möjligheter att uttrycka sig. Hon kan tala eller att vara tyst. Hon kan uttala sig med utgångspunkt från ett perspektiv eller välja ett annat. Inom sig bär den intervjuade flera olika möjligheter till uttalanden. Det hon slutligen kommer att säga utgör en av flera möjliga sätt att uttala sig. Den tredje och sista aspekten är intervjuns repetitiva aspekt. Den framhåller värdet av att intervjun inte utformas som en engångshändelse, utan som en händelse som upprepar sig. Allt är inte möjligt att säga vid ett och samma tillfälle. Olika tidpunkter erbjuder olika uttrycksmöjligheter.

\section{Forskningsintervjuns interaktiva aspekt}

Mitt forskarideal är en forskare som inte främst intar frågarens roll, utan lyssnarens. På motsvarande sätt är mitt informantideal en person som kan berätta. Under intervjun intar forskare och informant komplementära roller, där den intervjuades berättarposition möjliggör forskarens lyssnarposition. Att tilldela forskaren lyssnarrollen, betyder inte att jag förordar en passiv forskarroll. Tvärtom är min "idealforskare» mycket aktiv $i$ att skapa förutsättningar för den intervjuade att formulera sig så fullödigt och mångfacetterat som möjligt. Interaktionen mellan intervjuare och intervjuad är här av avgörande betydelse. Några interaktiva teman är mer centrala än andra (figl, nästa sida).

\section{Relationen mellan intervjuare och intervjuad}

Forskarens ansvarstagande utgör en viktig rambetingelse i uppbyggnaden av en intervju som syftar till att underlätta och stödja informanten i ett fritt berättande. Speciellt gäller detta om det är ett känsligt ämne, eller en pågående process, intervjun gäller. Informanten har mindre möjlighet att själv kontrollera en sådan intervjusituation, jämfört med en intervju om en vardaglig erfarenhet som ligger längre tillbaka i tiden. För att informanten skall kunna tala, krävs att forskaren tar på sig ansvar för att bryta in och hjälpa till med avgränsning, om situationen förefaller att bli alltför känslomässigt plågsam eller kaotisk. Det är viktigt att detta ansvarstagande blir uttalat. I min praktiska erfarenhet har det dock endast varit vid få tillfällen jag känt mig föranlåten att av- 
Figur 1

Relationen mellan intervjuare och intervjuad

$\begin{array}{lll}\text { Position } & \text { Intervjuare } & \text { Intervjuad } \\ \text { Lyssnare } & \text { Berättare } \\ \text { Interaktiva teman } & \text { I) Skapar psykologiskt } & \text { I) Talar med undanglidandets röst } \\ & \text { utrymme } & \\ \text { 2) Agerar hjälpröst } & \text { 2) Talar med oppositionens röst } \\ \text { 3) Tar emot sakupplysningar } & \text { 3) Talar med tydligare röst } \\ \text { 4) Tar emot narrativa upplysningar } & \text { 4) Ger sakupplysningar } \\ \text { 5) Ger narrativa upplysningar } & \end{array}$

bryta för att fråga om informanten verkligen vill fortsätta att tala om ett plågsamt tema. Det har tvärtom förefallit som om mina informanter haft positivt utbyte av att verbalisera svåra känslor och erfarenheter. Oftare än att helt byta tema, har jag där emot funnit det påkallat att övergå till att arbeta mer stödjande därför att det känslomässiga klimatet så krävt.

Tiden utgör en annan central rambetingelse. Mina intervjuer är inte längre än $60 \mathrm{mi}$ nuter. Om intervjupersonen har mycket att säga, eller om intervjun varit "trög" i starten, föredrar jag att upprepa intervjun framför att förlänga tiden. Det är svårt för såväl intervjuare som intervjuad att hålla koncentrationen under lång tid. På denna punkt råder dock delade meningar bland forskare. Vissa forskare menar att långa intervjuer kan vara att föredra framför de uppdelade. Så som jag ser det är inte det viktigaste vilken princip om tidens betydelse forskaren ansluter sig till. Det viktigaste är att ha en princip och meddela informanten denna och inte låta »det bli som det blir».

Två interaktiva teman kom att utgöra centrala kännetecken för intervjuarbetet med kvinnorna i uppbrottsstudien (2). Bägge dessa teman rörde kvinnornas svårigheter att artikulera sig. För att underlätta tilldelade jag mig två olika uppgifter. Den ena var uppgiften att försöka skapa ett psykologiskt utrymme för kvinnan. I grunden handlar denna uppgift om att markera en beredskap att lyssna och att undvika att ha någon färdig "grundberättelse» att försöka förmå informanten att "skriva in" sin berättelse i. Detta kan ju vara lättare sagt än gjort. De flesta studier utgår från något slag av teoretiskt perspektiv eller förförståelse, och att "skriva in" ytterligare empiri i detta perspektiv kan vara ett uttalat ideal. I mina undersökningar om kvinnomisshandel var jag inte intresserad av att utgå från något speciellt perspektiv. Det var kvinnornas och männens egen förståelse om vad som hade hänt som var i centrum för mitt intresse och den inre logik, eller brist på logik, jag kunde finna i deras utsagor om det som hänt. Temat "skapa psykologiskt utrymme» kom att få stor betydelse under bägge mina undersökningar om kvinnomisshandel, inte minst därför att de flesta av mina informanter hade stora svårigheter att artikulera sig. 
Den andra uppgiften var att försöka agera hjälpröst genom att erbjuda informanten en röst som stöd för sitt eget formulerande, en röst som det gick att förhålla sig till och ta spjärn emot. Förmågan att uttrycka sig empatiskt är här av avgörande betydelse. Empatiska uttryck är viktiga när det gäller att hjälpa den intervjuade att komma i kontakt med och uttrycka de känslor och tankar som inte är helt klara för vederbörande. Intervjuaren som agerar hjälpröst »lånar ut sin röst « genom att be om klargöranden eller presenterar tentativa tolkningar av utsagan, men poängterar att eventuella oklarheter och tolkningar kan vara uttryck för ett av många möjliga sätt att tänka och tala. Begreppet "röst" härstammar från Mikhail Bakhtins arbete: "An utterance, spoken or written, is always expressed from a point of view (a voice), which for Bakhtin is a process rather than location. Utterance is an activity that enacts differences i values» (Clark and Holquist 1984, s. 10.) Så som jag använder begreppet röst betyder det ungefär »ett sätt att omtala en händelse», "en framställelseform». Det vill säga, begreppet avspeglar en viss relation mellan framträdande, händelse och språk. Begreppet »hjälpröst» betyder ungefär »en röst som ställer sig till förfogande för att hjälpa någon att artikulera sig tydligare". Avsikten med att "låna ut sin röst" på detta sätt är att motparten i en dialog skall kunna få möjlighet att pröva olika vägar att omtala en händelse, tills han eller hon når fram till en framställelseform som har en rimlig bärkraft.

\section{Att skapa ett psykologiskt utrymme}

Att markera närhet och undvika att skapa avstånd när det gäller att intervjua kvinnor som varit utsatta för svåra trauman, är inte speciellt svårt. En intervjuare utrustad med en normal empatisk förmåga känner stark medkänsla med en traumatiserad person. För att överhuvudtaget kunna etablera en relation är det nödvändigt att utveckla en känslomässig grund byggd på närhet, som kan tjäna som en affektiv baslinje för samtalet. Men det räcker inte. I intervjuarbete med människor vars psykiska och kroppsliga integritet blivit allvarligt kränkt, är det av lika stor betydelse att utrymme skapas genom att visa respekt och hålla avståndet. Detta kan vara svårt, därför att intervjuaren som ett utslag av sin medkänsla kan komma att dras allt närmare den intervjuade utan att vara riktigt medveten om detta.

Hur kan man skapa ett psykologiskt utrymme som bygger på närhet, avstånd och respekt i lagom proportioner? Ett sätt är att regelmässigt uppmana informanten att utvidga sitt resonemang (»kan du fortsätta att berätta vad som hände», "påminner detta dig om något du tidigare varit med om", "fortsätt!", "finns det något mer att säga om det härı). Ett annat sätt är att uppmuntra informanten att använda olika framställelseformer i berättandet (»kan du ge mig ett exempel", »kan du berätta om någon gång det hände», "är det möjligt att ge mig en bild en färg - en doft - som skulle kunna uttrycka det du talar omı). Det underliggande budskapet i detta sätt att arbeta är att det faktiskt är möjligt att distansera sig från det man talar om, för att kunna betrakta det ur olika infallsvinklar och på så sätt ge sig själv 
utrymme. Utöver detta förmedlas budskapet att den intervjuades röst är värdefull och väl värd att lyssna till ur så många aspekter som möjligt.

\section{Att agera hjälpröst}

När informanten talar med undanglidandets röst

Ett speciellt behov av att använda forskarens röst som "hjälpröst« att förhålla sig till och ta spjärn emot har de informanter vars egna röster är svaga eller på annat sätt otydliga. En form av svag och otydlig röst är den som jag skulle vilja kalla »undanglidandets röst». En sådan framställelseform präglas av diffusa och undvikande yttrande som vjag vet inter och »kanske». I början av en intervju vållar i allmänhet denna typ av yttranden inte så stora problem. De är mer eller mindre förväntade när det gäller ett möte mellan två främmande personer, speciellt om mötet gäller ett känsligt ämne. Problem uppstår när det undanglidande talet blir dominerande.

Ett sätt att förstå det undanglidande sättet att tala om det som hänt $\mathrm{i}$ intervjuer med misshandlade kvinnor, är att talet speglar en osäkerhet och bristande självtillit från informantens sida. En annan möjlig tolkning är att det utgör eko av en tidigare dialog - den mellan henne och honom. I förhållande till den misshandlande mannen har kvinnan haft mycket att vinna på att vara otydlig. En kvinna som lever med en våldsam man riskerar att väcka hans vrede om hon klart artikulerar sin egen uppfattning och vilja. Sett ur detta perspektiv är undanglidandets röst mycket effektiv. Det blir svårt för mannen att få reda på ens det elementära när det gäller hennes uppfattning och känslor. Men problem uppstår i förhållande till henne själv: hur skall hon någonsin kunna vara någon om hon inte kan ge uttryck för sig själv? Problem uppstår också i förhållande till forskaren när kvinnan har något hon vill kunna berätta om.

För att belysa dessa problem vill jag ta ett exempel ur studien om misshandlade kvinnors uppbrott. Vi möter en ung kvinna, Fredrika 21 år, i hennes första intervju. Fredrika har varit utsatt för mycket allvarlig misshandel med inslag av sexuellt våld. Intervjun äger rum på ett kvinnohus fyra veckor efter att hon kommit dit. Fredrika har svarat ja till att vara med i min undersökning, men varit tveksam till om hon egentligen hade så mycket att bidraga med. Hon tror inte att hon har något att säga som kan vara av värde. Jag har öppnat intervjun med att fråga hur hon trivdes på kvinnohuset och hon säger att det är bra, hon är van att bo på främmande ställen. Hon flyttade hemifrån mycket tidigt och reste sedan omkring. Nu känner hon sig orolig, rastlös. Jag frågar henne på vilket sätt hon tror att hennes oro skulle kunna komma att visa sig under de samtal vi planerat. Hon svarar att allt är så osäkert och att hon inte har svar på någonting numera. Jag uppfattar hennes osäkerhet som ett grundläggande kännetecken hos henne, och vill gärna försöka hålla fast vid detta tema. Jag försöker undvika att ta upp den negativa tråden om oro. I stället vill jag försöka börja med att få henne att uttrycka något som kan vara positivt $\mathrm{i}$ hennes värdering av sig själv. Följande dialog kom att utspela sig:

I: Så blir jag litet nyfiken på, som du nu är... är du nöjd med dig själv nuförtiden 
F: Ja, man kan säga...ja... både det ena och det andra...

I: $\mathrm{Mmm} \ldots$

F: om det där.....

I: $\mathrm{Mmm}$

F: Det är klart jag känner mig idag... jag känner mig mer nöjd med mig själv än jag var för ett år sedan.. bara för att gå tillbaka ett år...

Mina kommentarer inskränker sig till några allmänt understödjande, affektivt empatiska "mmm". Jag lade in mer av ett positivt bekräftande uttryck i dessa "mmm» än vad som syns i utskriften. Min förhoppning var att Fredrika skulle fortsätta att berätta utan för mycket inblandning från min sida. Jag uppfattade henne som mycket osäker och var rädd att hon skulle tystna eller okritiskt ansluta sig till det jag hade att säga, om jag var alltför vältalig under intervjun. Jag fick dock inte speciellt mycket utdelning på mina "mmm». Det jag fick reda på var att man kan säga både det ena och det andra om detta att vara nöjd med sig själv, och att hon var mer nöjd med sig själv nu än för ett år sedan. Hon reflekterade inte över sin osäkerhet, som jag hade önskat. Hon uttryckte den. I en strävan att fortsätta dialogen tog jag fasta på hennes sista mening, nu i en mer kognitivt än affektivt empatisk anda:

I: Vad var du så missnöjd med för ett år sedan

F: Ja usch... rädd och osäker och kände att jag aldrig skulle kunna komma ur

den där asken som man är i...

I: Mmm

F: det kändes som jag var instängd .....

I: Hängde det ihop med Janno eller var det överhuvudtaget...

F: Jag tänkte nog mer på det här med Janno... tror jag.....

I: Du berättade om åren innan Janno, du flyt- tade hemifrån tidigt.. man får en känsla av att du inte riktigt visste vad du sysslade med...

I detta korta avsnitt av intervjun kommer två teman upp, »instängdhet" och »osäkerhetw. Känslan av instängdhet benämns direkt, osäkerheten mer indirekt genom uttryck som "tror jag" och pauser mellan ord och meningar. Bägge dessa teman föreföll centrala. Jag stod inför möjligheten - och kravet - att välja. Jag valde att försöka fortsätta utforska temat »osäkerhet». Jag utgick ifrån den osäkerhet som kom till uttryck i Fredrikas sista replik ("tror jag") och gick därifrån vidare med att anknyta till den osäkerhet hon talat om tidigare under intervjun - hennes resande när hon mycket ung flyttat hemifrån. Min förhoppning var, att genom att lyfta fram ett så negtivt tema som "osäkerhet" och ge det en betydelse i intervjun, skulle jag förmedla budskapet att inte något tema var för obetydligt eller för otydligt för att utforskas. Till en början misslyckades mina försök. Att möjliggöra ett öppet utforskande föreföll snarare göra Fredrika ännu mer osäker. Hennes osäkerhet gjorde mig osäker - och jag kunde inte värja mig för denna osäkerhet utan föll in i den tills hela intervjusekvensen flöt ut totalt:

I: Du berättade om åren innan Janno och att du flyttade hemifrån tidigt man fick en känsla av att du inte riktigt visste vad du sysslade med... for mest omkring...

F: Prövade litet här och litet där ....

I: Litet lätt planlöst på något sätt....

F: Mmm ganska lätt så där, litet flyktaktigt faktiskt... att inte ha någon plan...

I: Just det.

Mitt försök att utforska temat osäkerhet, föreföll dömt att sluta i just - osäkerhet. På 
längre sikt rönte mina försök större framgång. Allteftersom intervjuprocessen fortskred, blev Fredrika allt tydligare i sina uttalanden och tog upp även till synes obetydliga och knappt uttalade ämnen till utforskande.

Detta arbetssätt förutsätter att man arbetar med en forskningsdesign som innefattar en serie upprepade intervjuer. Om man i en engångsintervju möter en osäker informant som har svårt atta artikulera sig, skulle jag snarare vilja rekommendera att man går motsatt väg, och bygger upp intervjun kring det uttalade och tydliga. Annars är det lätt hänt att det enda man lyckas åstadkomma är att göra informanten ännu mer osäker. Om det är fråga om en undersökning med upprepade intervjuer - vilket är att föredra när det gäller osäkra personer - kan den väg jag valde vara lämplig, då den på sikt kan bygga upp en större säkerhet och förmåga till reflexion hos informanten och därmed öka tillförlitligheten i utsagorna.

Vare sig det gäller upprepade- eller engångsintervjuer, är intervjuarens affektivt eller kognitivt empatiska uttalanden betydelsefulla. Med empati menas i detta sammanhang förmågan att sätta sig själv $i$ informantens position, och leva sig in i hur det är att vara vederbörande. Utifrån denna position finner forskaren lättare uppslag kring hur hon eller han skall kunna föra dialogen vidare. De affektivt empatiska uttrycksmedel som jag främst använt mig av i intervjuarbetet har i allmänhet inskränkt sig till ett "mmm", som dock kan sägas på många olika sätt och därmed ges olika innebörd. Starka affektivt empatiska uttryck som "vad fruktansvärt, vad hemskt, vad rädd du måste ha varit« är sparsamt förekommande i mina in- tervjuer. Det har dock hänt att jag blivit så gripen av ett känslomässigt uttryck från informantens sida att jag börjat gråta eller givit ett starkt uttryck för glädje. Kognitiv empati handlar om att följa informantens tankar och tankebanor. Det kan ta sig uttryck i en bekräftelse av vad informanten sagt genom att be henne fortsätta utveckla en tankebana, eller be henne att pröva en tanke som man uppfattar ligger latent.

Mitt resonemang om behovet av att forskaren ställer sin röst till förfogande som »hjälpröst» för den informant som talar med en undanglidande röst, bygger på tanken att när en person berättar om sig själv för en annan person som visar intresse för att förstå hennes erfarenheter, inbegriper denna talakt också en invitation till utvidgad självreflexion. Detta blev mycket tydligt i undersökningen om misshandlade kvinnors uppbrottsprocess. Endast undantagsvis hade kvinnorna tidigare talat med någon om det som berördes i intervjun. På så sätt existerade inte kvinnornas uttalanden på förhand, som registrerade fakta i deras liv, utan de skapades genom datainsamlingen. Detta betyder, att den kvinna som uttrycker sig med en undanglidande röst talar så som hon kan tala om det som hänt, inför en person som hon först inte känner alls, och som hon kanske också aktivt vill undanhålla vissa uppgifter för. Den person som talar med "undanglidandets röst« kan inte på något enkelt sätt utveckla en tydlig och »egen« berättelse. Det är intervjuarens uppgift att utveckla ett interaktionsmönster så beskaffat, att en utveckling mot en tydligare uttryckt "egen" berättelse möjliggörs. Att ställa sin röst till förfogande betyder inte att forskaren skall överrösta informanten och formulera en ut- 
saga som det bara är att ansluta sig till. Att forskaren enbart får lyssna till ekot av sin egen röst är tämligen meningslöst, men lätt hänt vid intervjuer med informanter som talar med svaga röster. Syftet med att ta sig an uppgiften att agera hjälpröst är att undvika att detta inträffar.

\section{När informanten talar med oppositionens röst}

Samtliga kvinnor i uppbrottsundersökningen talade dock inte med undanglidande röster. Vissa talade högt och till synes tydligt, med det jag valt att kalla "oppositionens röst«. Detta uttryckssmönster tilltalade mig till en början. När jag mötte det första gången tänkte jag att »här har jag en kvinna som är bestämd och säker i sina uttalanden. Det gör det lätt för mig som intervjuare». Jag upptäckte dock ganska snart att även detta sätt att tala kunde rymma stor osäkerhet. I citatet nedan möter vi Helen 28 år, i hennes tredje intervju i undersökningen om misshandlade kvinnors uppbrott. Helen är mamma till fyra barn mellan 14 och tre år. Hon har blivit svårt misshandlad under flera års tid. I misshandeln har också funnits inslag av grovt sexuellt våld. Intervjuerna med henne präglades av att hon uttalde sig mycket bestämt - men knapphändigt. Varje försök till att få henne att utveckla sitt resonemang genom att be om ett klargörande eller ge förslag till tentativa tolkningar av vad hennes uttalande kunde tänkas innehålla, möttes med ett «nej, så är det inte», följt av tystnad. Min följdfråga »hur är det då besvarades med „det vet jag inte», ny tystnad. Ibland ackompanjerades yttrandet "det vet jag inte» av en irriterad grundton, ibland av ett mer neutralt »det vet jag inte - men det är i alla fall inte så som du sa». Tystnad igen. I intervjuavsnittet nedan har samtalet just kommit in på temat "vara nöjd med sig själv«:

H: Jag tycker själv att jag inte är nöjd med det jag gör det låter jag gå så hårt åt mig själv, tillbaka, jag grubblar väldigt mycket över det och är alldeles upptagen av det.. jag känner lite utav den där handlingsförlamningen.....

I: Det låter som om du är väldigt sträng mot dig själv

$\mathrm{H}$ : Nej det är jag inte alls.

I: $\mathrm{Mmm}$.

H: .......... (tystnad)

Avsikten med mitt inlägg ("det låter som om du är väldigt sträng mot dig själv«) var att ge Helen en kommentar som låg i linje med det hon själv sagt, men förskjuta innebörden något. När jag försökte förstå varför hon avvisade mitt uttalande, var min första tanke ett tämligen okomplicerat konstaterande: jag hade väl fel, bra att hon sa ifrån och inte gled undan. Men när hon mer som regel än undantag sade «nej« efter en kommentar från min sida, tänkte jag att varje gång kan jag väl inte ha så helt fel. Kunde det vara så att jag hade en kvinna framför mig som hade svårt att artikulera sig i positiva termer ("så här tänker jag") utan hade lättare att uttrycka sig i negativa termer ("så här tänker jag inteil)?

Längre fram i min kontakt med Helen, visade det sig att hennes problem var just detta, att hon inte kunde använda sitt «nej« som utgångspunkt för att formulera ett "ja», ett "så här är det i stället". Jag beslöt mig för att systematiskt försöka hjälpa att uttrycka sig i riktning mot "så här är det«. Min främsta metod var att ge henne möjlighet att pröva 
olika ståndpunkter. Jag gav henne förslag på olika möjliga sätt att uppfatta det hon sade och frågade om något stämde med det hon ville säga. Jag sammanfattade delar av hennes berättelse och tog upp möjliga trådar att gå vidare med. Jag bad om klargöranden på vissa punkter. Efter varje sådant inlägg var jag noga med att påpeka att det jag sade endast var tänkt som ett förslag, inte som ett diktat.

Det här var en metod som inte gav omedelbar utdelning. Liksom i intervjuerna med Fredrika fick jag ha tålamod. Helens "nej» blev dock allt mindre kategoriskt och mer sökande. Följande citat är från slutet av den tredje intervjun. Vi är återigen inne på temat "vara nöjd med sig själv", vilket är ett stort tema för Helen. Jag har åter påpekat att jag tycker det verkar som att hon är väldigt sträng mot sig själv. En ny ton som brutit sig in i Helens sätt att tala. Hon har börjat att reflektera mer över sig själv. Hon uppfattar inte längre mina inlägg som faktiska uttalanden som skall gälla och som hon därför måste ta avstånd ifrån. Nu svarar hon:

H: Jag vet inte om det verkligen är så... det vet jag inte... men jag har en väldig oro för att jag skall bli förkastad.... det är det jag tror skall hända... tror jag.

Så kan hon trevande börja formulera sin rädsla och oro för att bli övergiven, en rädsla så stark att den styrt hela hennes liv och delvis är förklaringen till varför hon varit i det närmaste oförmögen att bryta upp ur ett destruktivt förhållande.

"The word in language is half someone else's skriver Mikhail Bakhtin i essän Discourse in the Novel (1981). Min huvudsakli- ga förståelse av vad som skedde vid det första intervjutillfället med kvinnorna som brutit upp, var att männen fortfarande var tydligt närvarande i kvinnornas utsagor. Såväl »opposition" som "undanglidande» uppfattade jag som röster som utvecklats i samspel med den misshandlande mannen. Om mitt intervjumaterial hade inskränkt sig till en enda intervju, och därmed begränsats till att fånga det som var möjligt för dessa röster att uttrycka vid detta enda tillfälle, vad hade det givit mig för analytiska möjligheter?

Ett sådant material hade givit mig information såväl i sak (det hade upplysningar att lämna om det våldsamma äktenskapets karaktär) som narrativ form (de hade upplysningar att lämna om sättet att tala om en våldshändelse). Bägge dessa röster har något att lära oss om hur det är att leva i ett våldsamt äktenskap, och vilken krympning av det egna självet och livsrummet kvinnor tvingas till under sådana levnadsomständigheter. Kvinnan som talar med undanglidandets röst kan fortfarande befinna sig i dialog med en dominerande man. Kvinnan som talar med oppositionens röst kan även hon befinna sig $i$ dialog med en dominant man, i en dialog som inte ger henne utrymme nog att formulera sig i positiva termer: så här tycker jag.

I min undersökning ville jag dock inte låta mig nöja med detta slag av utsagor. I min dialog med kvinnorna ville jag ta mig bortom dialogen med männen. För att beskriva mitt syfte, lånar jag åter Mikhail Bakhtins ord. På följande sätt fortsätter han sitt resonemang om att ordet i språket till hälften är någon annans: "It /the word/becomes 'one's own' only when the speaker populates it with his own intention, his own accent, 
when he appropriates the word, adapting his own semantic and expressive intention. Prior to his moment of appropriation, the word does not exist in a neutral and impersonal language (it is not, after all, out of a dictionary that the speaker gets his words!), but rather it exists in other people's mouths, in other people's concrete contexts, serving other people's intentions: it is from there one must take the word and make it one's own" (ibid. s. 293-294).

Att ta ordet och göra det till sitt. Det är en vacker formulering som beskriver den process jag försökte få till stånd i intervjusituationen: en forskningens samarbetsprocess, en dialog som skulle göra det möjligt för kvinnorna att formulera sin egen röst.

\section{Forskningsintervjuns polyfona aspekt}

Intervjuns polyfona aspekt rör relationen mellan berättare och berättelse. Som tydligt framgått har en informant olika möjligheter att variera sitt tal i en intervju. Är inte intervjun hårt strukturerad genom ett frågeschema, har hon/han möjlighet att gestalta sin framställning på olika sätt. Den kan göras mer eller mindre utförlig. Informanten kan välja att uttala sig med utgångspunkt från ett speciellt perspektiv under hela intervjun, eller skifta perspektiv under intervjuns gång. Hon/han kan jämföra hur hon/ han tänker nu med hur hon/han tänkte då (figur 2). Hon/han kan välja att tala eller vara tyst. Det som slutligen kommer att sägas, utgör en av flera möjliga utsagor. Inom sig bär informanten möjligheten att göra flera andra uttalanden. Varje intervjuad består på detta sätt av en hel kör av röster. Vissa informanter har svårt att utnyttja dessa möjligheter till mångfald. Det kan hänga samman med individuella faktorer, som svårigheter att finna ord som uttrycker den egna erfarenheten, eller med kulturella faktorer, som att det saknas varierade framställelseformer för att kommunicera just dessa erfarenheter. Begränsningar i informantens möjligheter att uttrycka sig, ställer krav på forskarens kommmunikativa kompetens.

Ett metodologiskt problem en intervjuare kan ställas inför i strävan att nå en fullödig utsaga, är att informanten uttalar sig tydligt och välartikulerat, men uttalandet

Figur 2:

Intervjuns polyfona aspekt

$\begin{array}{lll}\text { Position } & \text { Intervjuare } & \text { Intervjuad } \\ \text { Kommunikativa kompetenser } & \text { Lyssnare } & \text { Berättare } \\ & \text { I) Konfronterar } & \text { 1) Talar eller är tyst } \\ & \text { 2) Berom klargöranden, } & \text { 2) Uttalar sig begränsat } \\ & \text { utvikningar, kompletteringar } & \text { eller utförligt } \\ & \text { 3) Ger tentativa tolkningar } & \text { 3) Perspektiviserar } \\ \text { 4) Jämför utsagor } & \end{array}$


skapar ändå en känsla av otillfredställelse hos intervjuaren. Utsagan förefaller ofullständig och begränsad. Den synes utgå från ett alltför snävt perspektiv. Intervjuaren grips av misstro och misstänker att informanten har mycket mer att säga, kanske till och med har lämnat det viktigaste utanför. Ett inte ovanligt sätt att angripa detta problem är att under analysarbetets gång tillskriva utsagorna innebörder utöver det informanterna själva givit dem. På så sätt kan intervjumaterialet lättare låta sig fogas in $\mathrm{i}$ den teoretiska förståelseram forskaren ansluter sig till. Jag är motståndare till ett sådant arbetssätt. Jag menar att det forskaren har att utgå ifrån i analysarbetet är det som finns manifest $i$ intervjun och $i$ det sammanhang i vilket utsagan är given eller refererar till. Ingen möda bör sparas för att göra intervjun innehållsrik. Intervjun riskerar att förvanskas om forskaren i sin ensamhet vid skrivbordet vidgar dess meningsinnehåll.

I en undersökning som finns redovisad i en ofta citerad feministisk metodbok (Reinharz 1992 s. 28) beskrivs vad som hände sociologen Margaret Andersen (1981) när hon misstrodde sina informanter. Tjugo välutbildade yrkeskvinnor intervjuades om sitt liv i den amerikanska Södern. De hade samtliga givit upp sina yrken när de gifte sig, för att helt ägna sig åt hem och barn. När de intervjuades förklarade de sig nöjda med sitt liv. Andersen skrev sedan att de led av "falskt medvetande» och att de i själva verket inte var så nöjda som de framställt sig. Som svar på artikeln formulerade kvinnorna ett kollektivt genmäle. I ett brev tillbakavisade de kraftfullt Andersens tolkning. De menade att, bortsett från vad sociologer än påstod, fann de mening och möjlighet till självför- verkligande i sina roller som hustrur, mödrar och välgörenhetsarbetare. Deras bidrag till samhället var värdefullt och Andersens artikel var enbart ett uttryck för avundsjuka därför att de levde i en ekonomiskt privilegierade situation. Efter detta genmäle skrev Andersen ytterligare en artikel där hon bedrev självkritik och förfäktade åsikten att en riktig forskningsstrategi inte var att söka efter det som kunde vara oriktigt i kvinnornas berättelser, utan att se till kvinnornas faktiska levnadsomständigheter och undersöka på vilket sätt dessa omständigheter skulle kunna generera den belåtenhet som uttryckts. Enligt min mening borde detta meningsutbyte inte skett genom skriftväxling efter att undersökningen slutförts, utan ha ägt rum inom ramen för intervjun. Annorlunda uttryckt, det är inte nödvändigt eller ens önskvärt, att utan ifrågasättande godta det informanten säger. Att vara medveten om intervjuns polyfona aspekt betyder att vara medveten om att den utsaga man får ta del av, endast utgör en av flera möjliga.

\section{Att konfrontera informanten med sin berättelse}

En möjligen något drastisk metod för att förändra relationen mellan berättare och berättelse, praktiserade jag i den första undersökningen om kvinnomisshandel i intervjuer med männen. Det var inte enbart kvinnorna som hade svårt att uttrycka sina erfarenheter. Även de manliga informanterna hade formuleringsproblem, i vissa avseenden större än kvinnornas. Hur det är att misshandla sina närstående är inte något som människor gärna vittnar om. Männen i undersökningen var dock inte ovilliga att 
tala med mig. De var genomgående tämligen välformulerade när det gällde sådant som våldets förhistoria (som de oftast beskrev i termer av gräl som innehöll provokationer från kvinnan), men var mer återhållna när det gällde att beskriva själva våldsakten. Det männen presenterade för mig var tämligen stereotypa beskrivningar av att de inte kunde komma ihåg vad som hänt. Under dessa intervjuer greps jag av en tilltagande känsla av misstro och misstänkte starkt att det viktigaste blev lämnat utanför. I citatet nedan möter vi Jan i en tredje intervju. Han är polisanmäld för upprepad allvarlig misshandel av sin hustru. Han har i tidigare intervjuer svarat på frågorna whur började det" och "vad hände sedan" och då givit en utförlig beskrivning av sina och hustruns våldsamma gräl. När jag sedan bett honom fortsätta att berätta "vad som hände sedan" hade han stoppat. Så även denna gång:

J: Jag är rädd att jag inte kommer ihåg så mycket av vad som hände.

I: Mmm... försök och ta det från början.

J: Jag kommer ihåg att vi grälade... sedan kommer jag inte ihåg så mycket mer.

Att försöka få honom att komma vidare i sin berättelse genom att forma en relation som gav möjlighet till psykologiskt utrymme, hade rönt en viss framgång. Jag hade försökt att agera hjälpröst, och även då rönt begränsad framgång. Vid den tredje intervjun upprepade jag "vad hände sedan" ett par gånger, varpå följande dialog utspann sig:

J: Jag blev förbannad... hon kan bli väldigt tjatig... sen måste jag ha fått en blackout helt enkelt, för jag kom inte ihåg någonting förrän hon låg blödande på golvet... det var för djävligt... jag tror vi vart chockade båda två... jag vart tvungen att hjälpa henne..

I: Du fick en blackout... får du det ofta?

J: Ja... lite då och då..

I: Konstigt... hur kan det komma sig...?

J: Jo du förstår, det här är litet svårt att förklara, men det är så att uppe i huvudet finns på ett ställe två stycken... vi kan kalla dom poler. Dom ligger på ett visst avstånd från varandra, så här stort ungefär (visar med tummen och pekfingret ett avstånd på tre-fyra centimeter). När man druckit, då kommer dom där polerna närmare varandra, när man blir förbannad gör de det också. För mej är det så att dom där polerna sitter för nära varandra (visar ett par centimeter med tummen och pekfingret). När jag druckit och sen blir förbannad, då smäller dom ihop.

I: Hmmm...

J: Ja, jag ser på dej att du inte tror mej, men det är faktiskt sant. Det är faktiskt en läkare som sagt det där till mej, en neurolog som jag träffade efter att jag varit med om en motorcykelolycka.

I: Hur märker du det där, sa du?

J: Jag får en blackout helt enkelt. Jag blir förbannad, så PANG smäller det ihop.

Jag märker ingenting på en lång stund. När jag hänger med igen så har jag oftast gjort något våldsamt. Slagit till Pia (hans hustru) eller röjt i lägenheten.

Vad är det som händer här? En man beskriver hur hans hustru blivit allvarligt skadad i en situation där han varit väldigt arg på henne och de två är ensamma i lägenheten. Han använder sig av en framställningsform man kan också beskriva den som ett berättartekniskt grepp - som lämnar åhöraren i tvivelsmål om vad eller vem som förorsakat hustrun skada. Berättelsen inbegriper frånvaro av honom som ett handlande subjekt. Handlingen blir till något som svävar fritt utan att någon gör anspråk på den. Möjligen 
kan man tala om att de shopsmällda polerna» har subjektställning i hans framställning. Mannen förnekar inte att hans hustru utsatts för allvarligt våld och tillstår indirekt att han varit inblandad. Han beskriver sitt handlande i aktivt passiva termer. Handlingen framställs som något som faktiskt har ägt rum, oklart är vem som gjort vad. Fortsättningen har sitt ursprung i en tilltagande irritation från min sida, snarare än i en strävan att ytterligare utveckla min kommunikativa kompetens. Under intervjuerna med männen hade jag lyssnat till alltför många beskrivningar av minnesförlust: „Nej, jag kommer inte ihåg så mycket mer, om sanningen skall fram så var jag ganska full«. »Jag är som en tryckkokare PANG så kokar det över och då vet jag inte vad som händer«. I den fortsatta intervjun med Jan konfronterade jag honom med logiken i hans berättelse. Han formulerade sig då på ett sätt han inte gjort tidigare:

I: Då får man väl säga att det är en väldig tur att Pia lever överhuvudtaget.

J: Va, vaddå, vad menar du med det?

I: Jo, om man lyssnar till det du säger, så berättar du att du blir förbannad för att hon är så dum och tjatig och oförstående. Om jag förstod det hela rätt var du inte helt nykter heller. Så har du ju det där med polerna i huvudet som gör att det blir kortslutning, en blackout helt enkelt. Då rusar din kropp iväg alldeles för sig själv utan att du har koll på någonting. Vad är det som säger att kroppen inte nästa gång rusar ut i köket och hämtar förskäraren eller stekpannan eller vad som...

J: Nej vet du vad... du har ju inte fattat det mest elementära ... jag skulle aldrig kunna göra något sådant...

I: Men du får ju dina blackouts och då händer det...

J: Det här tycker jag inte är roligt! Aldrig att jag skulle kunna göra henne något sådant! Du kanske tror att jag spöar ungarna också! Det vill jag bara ha sagt, att jag älskar min fru... och ungarna... dom är ju allt... tror du inte att jag vet vad jag gör?

I: Nej det verkar faktiskt inte som du vet det.

Vårt meningsutbyte fortsätter ytterligare en stund. Jag håller fast vid mitt, han håller allt ihärdigare fast vid sitt. Från att ha beskrivit sig själv som en icke närvarande person utan förutsättning att kontrollera situationen, övergår han nu till att kräva att få bli betraktad som en i högsta grad närvarande person med ansvarskänsla och förmåga till kärleksfullhet.

Det är inte meningsfullt att utifrån denna förändrade utsaga föra ett resonemang om vilken version av vad som hänt som är den som är "sann" eller vilken som bör »väcka misstroende». Bägge beskrivningarna av vad som hände när mannen misshandlade sin hustru ger var för sig viktiga upplysningar. Att jämföra dessa utsagor och upptäcka skillnader och likheter, är det slag av analytiskt arbete som kan ge ytterligare kunskap om mäns sätt att tala om sig själva och det våld de utövat. Ett av de viktigaste resultaten i undersökningen om kvinnomisshandel inom äktenskapet härrör sig från en jämförande analys av det slag av utsagor Jan i citaten ovan lämnade. Denna analys ledde fram till formulerandet av tesen om "ansvarsbefrielsens retorik» och dess avgörande betydelse för upprätthållandet av våld inom äktenskapet (Hydén \& McCarthy 1994; Hydén 1995 s. 133-141).

\section{Forskningsintervjuns}




\section{repetitiva aspekt}

I ett ofta citerat arbete om feministisk forskningsmetod, rekomenderar Reinhartz (1992, s.36) användandet av upprepade intervjuer, för att de hjälper till att stärka banden mellan intervjuare och intervjuad. En annan feministist orienterad forskare, Liz Kelly (1988) föreslår användande av »followup» intervjuer, där huvudintervjun skrivits ut och den intervjuade ges tillfälle att läsa och kommentera den i en uppföljningsintervju. När jag föredrar att arbeta med en intervjuserie framför en enstaka intervju, är det inte för att skapa kontakt, utan för att det ger mig möjlighet till ett rikare material. När jag ville ta del av den innebörd en händelse som äktenskapligt kvinnovåld hade haft för de direkt inblandade, var det uppenbart att tiden utgjorde en avgörande faktor för vad som var möjligt för mig att få reda på. Vad som förefaller viktigt att tala om, eller vad som är möjligt att ens nämna, skiljer sig inte åt enbart beroende på vem vi talar med, utan också när vi talar om det. Det som vi är uppfyllda av när någonting just har hänt, är inte det samma som förefaller viktigt ett par månader senare. Vid första intervjutillfället i undersökningen om äktenskapligt kvinnovåld, talade männen om våldets förhistoria, som de flesta beskrev som ett gräl där bägge varit aktiva och hon kanske mest. Hon hade varit väldigt tjatig, direkt provocerande eller kränkande enligt männens uppfattning. Själva våldsutbrottet var inte männen intresserade av att närmare gå in på vid första intervjutillfället. Kvinnorna talade om våldsutbrottet i första intervjun. När det gällde våldets förhistoria var det främst en aspekt som intresserade dem: varför hade han slagit, varför hade han inte lyssnat eller försökt att lösa de problem som fanns? Vid de första intervjutillfällena var männen fortfarande närvarande i kvinnornas tal. "Oppositionen" och "undanglidandet" var påfallande i dessa intervjuer. Att vid ett och samma intervjutillfälle upprätta en öppnare och mindre stereotyp dia$\log$ visade sig näst intill omöjligt. Majoriteten av informanterna var "osäkra talare", det vill säga de behövde hjälp att artikulera sig, inte minst därför att de oftast tidigare inte talat med någon om det intervjun gällde. De behövde hjälp att bygga upp en större säkerhet och förmåga till reflexion.

Att förstå vad det är som händer när man lever i ett långvarigt misshandelsförhållande, innebär att vara involverad $i$ en process av ständigt förhandlande och tolkande av det som sker. Denna process fortsätter och får nya utvecklingsmöjligheter efter kvinnans uppbrott. När hon försöker förstå och finna ord för vad som hänt när hon blivit slagen, är det inte fråga om någon linjär process där förståelsen kan byggas upp genom att bit läggs till bit. Förståelsen rör sig snarare i cirklar eller cykler, där flera saker kan hända samtidigt utan nödvändigt inbördes sammanhang. I en sådan process kan ny förståelse komma till, och "gammal och övergiven" förståelse plötsligt framstå som högst relevant och rimlig. Genom att följa kvinnan i återkommande intervjuer kan forskaren få tillträde till denna process.

Det jag velat argumentera för genom att lyfta fram intervjuns repetitiva aspekt, är inte att alla intervjuundersökningar av nödvändighet skall byggas upp av intervjuer i serieform. Vad jag däremot vill framhålla är värdet av att ha en genomtänkt och reflekte- 
rad hållning i frågan om en enstaka intervju, eller en serie intervjer, kan vara att föredra i en specifik undersökning. Ytterst är det inte en fråga om vad man bör, utan en fråga om vilken kunskap som är möjlig att vinna.

\section{Slutdiskussion}

Våld mot kvinnor är ett komplext fenomen. Den grundförståelse som vuxit fram inom den etablerade feministiska kvinnovåldsforskningen i Sverige, erbjuder ett alltför begränsat utrymme för att kunna analysera dynamik och innebörd av kön i ett heterosexuellt parförhållande som är präglat av våld. Den bygger på en dikotomiserad förståelse av kön som bär tydliga särartsfeministiska drag. Det är 1970-talets världsbild som fortfarande råder. Det är som om den omprövning av den enhetliga uppfattningen av kön, som ägt rum inom feministisk forskning det senaste decenniet, aldrig nått fram. Utan tillgång till en mer komplex och pluralistisk förståelse, riskerar forskaren att stänga in sig själv i en evig upprepning av beskrivningen av »kvinna« som det goda, passiva offret, och "man" som den onde, aktive angriparen. Samma instängdhet riskerar att drabba den som i sin yrkesutövning möter misshandlade kvinnor och misshandlande män.

Arbetet med att utveckla den berättarfokuserade intervjun, har varit en del av ett arbete med det långsiktiga syftet att försöka utveckla en förståelse av kvinnomisshandel inom äktenskapet som fångar fenomenet, utan att reducera det alltför kraftigt. Jag tror dock att metodens användbarhet inte är begränsad endast till våldsforskning. Jag tror att den även lämpar sig för forskning om andra slag av mänsklig erfarenhet som är komplex och svår att benämna. Målet med den berättarfokuserade intervjun är att göra det möjligt för den intervjuade att formulera sig i en så fullödig och mångfacetterad berättelse som möjligt. I en sådan intervju kommer inte den intervjuade att uttrycka en enda röst. Tvärtom kommer intervjun om den är lyckad - att innehålla en hel kör av röster som bryts mot varandra. Stabiliteten i berättelsen ligger snarare i det återkommande omprövandet och reflekterandet, än i upprepandet av en och samma beskrivning. Detta ger forskaren möjlighet att göra jämförelser.

Den bärande tanken i artikeln är, att en intervju är en form av social interaktion, och att intervjuare och intervjuad samspelar i rollerna som lyssnare respektive berättare. I allt väsentligt kan intervjun beskrivas som en relationell praktik, det vill säga det är forskarens förmåga att skapa en relation till den intervjuade som är avgörande för om målet med intervjun kommer uppnås eller inte. I detta samspel har jag tilldelat intervjuaren-lyssnaren, rollen av att vara den som systematiskt arbetar för att få den intervjuade att öka sin förmåga till självreflexion. Jag har velat beskriva hur man kan strukturera intervjun och lägga upp samtalet för att nå detta mål, och jag har velat ge exempel på hur lätt det är att som intervjuare styra intervjun. Det är oändligt mycket svårare att lära sig föra ett samtal som kan ge en möjlighet för en ny röst att göra sig hörd, än att få höra ekot av sin egen röst i en berättelse som bekräftar det man redan vet.

Förutom att vara forskare, är jag verksam som psykoterapeut. Jag är således inbegri- 
pen i flera "relationella praktiker" parallellt. Ibland får jag frågor om hur jag kan undvika att blanda dem samman, för att inte ställa till med förvirring. Jag brukar svara att det är inte så svårt, eftersom dessa "praktiker" har stora likheter, men också skiljer sig åt på viktiga punkter. Anledningen till varför människor söker psykoterapi kan beskrivas som en upplevd brist på kontroll över det egna livet, vare sig denna kontrollförlust tar sig uttryck i form av ett symtom man inte kan hantera (ångest, oro, depressivitet, sömnsvårigheter), traumatiska upplevelser som plågar eller hindrar, eller svårigheter i relation till andra människor. Min roll som terapeut består av att stödja, bekräfta, begripliggöra, syntetisera - men också av att tillsammans med patienten utforska och utmana invanda föreställningar. Terapeutens roll i den explorerande delen av den terapeutiska processen äger stora likheter med forskarrollen, de bekräftande och begripliggörande rollerna gör det inte i lika hög grad. Mitt uppdrag som terapeut är att hjälpa patienten att återfå kontrollen och hantera sina svårigheter, det terapeutiska kontraktet handlar om samarbete terapeut-patient $i$ syfte att uppnå detta mål. Mitt uppdrag som forskare är att söka efter kunskap som är giltig bortom det enskilda, det forskande kontraktet handlar om samarbete forskareinformant i syfte att uppnå detta mål. Min roll som forskare är utforskarens, som söker efter aspekter på fenomen som kan utgöra komplement till rådande kunskap, men även erbjuda alternativ, som kan utmana och som kan ha bärighet att utgöra en ny stämma i en pågående kör. Som terapeut befinner jag mig i dialog med min patient. Som forskare befinner jag mig i dialog med min informant, men befinner mig samtidigt i dialog med forskarvärlden och den rådande diskursen. I forskning är explorerande och kunskapsproduktion ett mål i sig. I terapeutiskt arbete kan det utgöra en del i en begripliggörandeprocess, med syfte att göra det möjligt för patienten att erövra kontroll och valmöjligheter. Terapeuten har tystnadsplikt, forskaren har publikationsplikt.

Det skulle föra alldeles för långt att ge någon uttömmande beskrivning av resultatet av min strävan att samla ett gott empiriskt underlag för att bättre kunna förstå fenomenet kvinnomisshandel. Några korta ord avslutningsvis. Mitt sätt att intervjua gav mig material som visade, att "man" och "kvinna" i misshandelsförhållandet inte enbart är knutet till positionerna dominans och underordning. "Man« är i lika hög grad knutet till bristande ansvarstagande och oförmåga att vinna och upprätthålla respekt för sin manliga position. "Kvinna» är i lika hög grad knutet till motstånd mot våld och till uppbrott ur förhållandet. "Man« är knutet till anspråk på en patriarkalt överordnad position, men med en tydlig oförmåga att upprätta hålla den. "Kvinna» är snarast knutet till en ambivalent inställning, såäl till mannens anspråk som till hans oförmåga. 


\section{Fotnoter}

(1) Studien av kvinnomisshandel inom äktenskapet

För mitt första forskningsprojekt om kvinnomisshandel (Hydén 1994; 1995a; 1995b; Hydén \& McCarthy 1994) valde jag ut tjugo par där kvinnan anmält mannen för misshandel hos polis eller sociala myndigheter. I samtliga fall hade kvinnan utsatts för upprepat våld under ett till sjutton års tid. För detta forskningsprojekt genomförde jag sammanlagt 143 intervjuer, 30 med män och 59 med kvinnor individuellt, 54 med paret gemensamt.

Min strävan var att förstå. Jag ville förstå kvinnomisshandel i äktenskapet såväl ur kvinnans som mannens perspektiv och jag ville ta del av den gemensamma förståelse de utvecklat - den som möjligen skulle kunna förklara hur äktenskapet hade fortlevt trots upp till sjutton års misshandel. Jag ville få en bild av vad för slags händelse det äktenskapliga kvinnovåldet var, så som det framstod i misshandlade kvinnors och misshandlande mäns berättelser. När mannen hade slagit kvinnan, vad var det då som hände, så som paret uppfattade det? Vad betydde denna handling för dem, som offer och förövare? Vad betydde denna handling för deras uppfattning om sig själva, sina liv och sitt äktenskap? Hur definierade, tolkade och förklarade de det våld han utsatt henne för? Tog de avstånd från det eller försökte de rättfärdiga det? Uppfattade de det som skett på liknande sätt? Ändrades denna förståelse över tid? Mina frågor var många men de gick i samma riktning.

Det jag fann var att männen och kvinnorna gav olika namn åt det som hänt. Männen talade om "bråk« - och detta trots att polisen rubricerat våldshändelsen som misshandel och trots att flera män senare blev dömda för misshandel. Kvinnorna tvekade inför hur de skulle benämna det som skett. De ville inte kalla det bråk, men heller inte misshandel. De lade en speciell betydelse i ordet misshandel, nämligen om det var fråga om misshandel, då skulle det betyda att de var misshandlade kvinnor, en kategori ingen ville tillhöra. En "misshandlad kvinna» betydde en oälskad och icke respekterad kvinna för de flesta av mina kvinnliga informanter. Vad jag också fann, var att männen framställde våldet så att de inte förnekade att det inträffat, men att de trots att de tillstod att det hade skett, framställde det på ett sådant sätt att de frånsade sig ansvar för det som hänt. Jag kom att benämna detta sätt att tala »ansvarsbefrielsens retorik" (Hydén 1995 s. 133141). Vidare fann jag, att de par som kom att fortsätta tillsammans efter undersökningstidens slut (vilket var knappt hälften av de ursprungliga tjugo paren) formulerade en gemensam berättelse om vad som hade hänt, en berättelse som inbegrep mannens befrielse från ansvar för vad han gjort. En av undersökningens slutsatser var att mannens ansvarsbefrielse utgjorde en förutsättning för äktenskapets fortlevande på lång sikt, samtidigt som det innebar en möjlighet för mannen att fortsätta bruka våld (ibid., s. 213-237).

Studien finansierades genom bidrag från Delegationen för Social Forskning.

\section{(2) Studien av misshandlade kvinnors uppbrott}

Som informanter valde jag tio kvinnor som sökt skydd vid ett kvinnohus efter att ha lämnat sina våldsamma män. Kvinnorna intervjuades vid sex olika tillfällen med ungefär fyra månaders intervall. Intervjuerna ägde rum på kvinnohuset så länge kvinnorna bodde kvar där, sedan i deras hem. Samtliga kvinnor hade blivit utsatta för svår och upprepad misshandel i sina äktenskap eller samboförhållanden.

Inför den första intervjun förberedde jag två frågor: »hur kommer det sig att du bryter upp just nu?" samt "hur är det nu, vad är centralt i ditt liv just nu? «Den sista frågan upprepades vid vart och ett av de följande intervjutillfällena. Ytterligare två frågor ställdes vid dessa senare intervjuer: "hur påverkas ditt nuvarande liv av det våld du varit utsatt för?" och "hur förhåller du dig till dessa våldshändelser nu?" Det jag fann var att kvinnornas uppbrott var 
en process, och inte en enstaka händelse (Hydén 1999 a). Tiden innan kvinnan lämnat mannen hade utåt sett varit en odramatisk period, då hon dragit sig tillbaka och förhållit sig så passiv som möjligt. Inom henne pågick en dialog som innehöll stor dramatik, beskriven som att Döden blivit något påtagligt närvarande. Kvinnans röst i denna dialog var motståndets röst. Kvinnorna beskrev det som hänt som att de aldrig tagit något direkt beslut om att lämna mannen. Däremot hade de bestämt sig för att de ville leva. Rädsla (Hydén 1999 b) och självanklagelser utgjorde uppbrottsprocessens psykologiska grundtema. Dessa tema ändrade kvalitet över tid.

Studien finansierades genom bidrag från Forskningsrådsnämnden.

\section{Summary \\ Listening to a chorus of voices The teller-focuse interview}

If we social work researchers want to get accounts from people whose experiences have never before been expressed in words, how should we proceed? If we want to be open towards a complex and pluralistic comprehension of gender, what consequences will this have for our methods? The interview form presented in this article - the teller-focused interview - was developed as an attempt to answer to these questions.

By using examples from two studies of battered women, a description is given of an interview method which focuses on the person being interviewed, and is constructed with the idea of facilitating and lending support to the narration. The interactive aspect of the interview, as well as its polyphonic and repetitive aspects, make up the cornerstones of this interview-form. It is especially designed for studies of ongoing events, and for studies of sensitive subjects. It is emphasized in the article that the researcher's ability to create a respectful relationship with the person interviewed is of primary importance.

\section{Litteratur}

Andersen, M. (1981). Corporate Wives: Longing for Liberation or Satisfied with the Status Quo? Urban Life, 10(3), 311-327.

Bak, M. (1997). Enemorfamilien som senmoderne familieform. Köpenhamn: Förlaget Sociologi.

Bakhtin, M. M. (1981). The Dialogic Imagination: Four essays by M.M. Bakhtin, ed. Michael Holquist, trans. Caryl Emerson and Michael Holquist. Austin: University of Texas Press.

Banister, P.; Burman. E.; Parker, I.; Taylor M.; and Tindall C. (1994). Oualitative Methods in Psychology. A Research Guide. Buckingham: Open
University Press.

Butler, J. (1990). Gender Trouble. New York and London: Routledge.

Clark, K. \& M. Holquist (1984). Mikhail Bakhtin. Cambridge, MA: Harvard University Press.

Collins, Patricia Hill (1990). Black Feminist Thought: Knowledge, Consciousness, and the politics of Empowerment. Boston: Unwin Hyman.

Connell, R.W. (1995). Masculinities. Berkeley: University of California Press.

Franklin, M.B. (1997). Making Sense: Interviewing 
and Narrative Representation. In M.B. Gergen \& S.N. Davis: Toward a New Psychology of Gender, 99-116. New York and London: Routhledge.

Gergen, M. \& Davis, S. (1997). Toward a New Psychology of Gender. New York and London: Routhledge.

Gilligan, C. (1982). In a Different Voice. Cambridge, MA: Harvard University Press.

Gunnarsson, E. (1993). I välfärdsstatens utmarker. Om socialbidrag och försörjning bland ensamstående kvinnor utan barn. Stockholm: Rapport i socialt arbete nr 64-1993. Stockholms Universitet, Socialhögskolan.

hooks, b. (1984). Feminist Theory: From Margin to Center. Boston: South End Press.

Hydén, M. (1994). Woman Battering as Marital Act. The Construction of a Violent Marriage. Oslo: Scand. Univ. Press.

Hydén, M. \& McCarthy, I. (1994).»Woman Battering and Father-Daughter Incest Disclosure: Discourses of Denial and Acknowledgement." Discourse and Society, 5, 543-565.

Hydén, M. (1995a). Kvinnomisshandel inom äktenskapet. Mellan det omöjliga och det möjliga. Stockholm: Liber.

Hydén, M. (1995b). „Verbal Aggression as PreHistory of Woman Battering" Journal of Family Violence 10, 55-71.

Hydén, M. (1995c).»Mot en förståelse av misshandel som en social process". Kvinnovetenskaplig. tidskrift 16 (4), 67-74.

Hydén, M. (1999 a). »Mäns ansvar och kvinnors motstånd. En helhetssyn för socialt arbete med män som slår och kvinnor som blir slagna» Socionomen 6/99.

Hydén, M. (1999 b). »The World of the Fearful: Battered Women's Narratives of Leaving Abusive Husbands. Feminism \& Psychology, 9 (4), 449-469.

Kelly, L. (1988). Surviving Sexual Violence. Cambridge, UK: Polity Press.
Lather, P. \& Smithies, C. (1997). Troubling the Angels. Women Living with HIV/AIDS. Boulder, Colorado: Westview Press.

Lykes, M.B. (1997). „Dialogue with Guatemalan Indian Women: Critical Perspectives on Constructing Colloborative Research". In M.M. Gergen \& S.N. Davis: Toward a New Psycholgy of Gender, 129-148. New York and London: Routledge.

Mishler, E. (1986). Research Interviewing. Context and Narrative. Cambridge, MA: Harvard University Press.

Månsson, S-A. (1984). Kärlek och kulturkonflikt. Invandrarmäns möte med svensk sex- och samlevnadskultur. Stockholm: Socialstyrelsen.

Månsson, S-A \& Linders, A. (1984) Sexualitet utan ansikte. Könsköparna. Stockholm: Carlssons.

Nicholson, L. J. (1989). (Ed.). Feminism/Postmodernism. New York: Routledge.

Reinharz, S. (1992). Feminist Methods in Social Research. Oxford: Oxford University Press.

Riessman, C.K. (1997). „Berätta, transkribera, analysera» I: L-C. Hydén \& M. Hydén: Att stu dera berättelser, 30-55. Stockholm: Liber.

Sherman, E. \& Reid, W. R. (1994) (eds.). Qualitative Research in Social Work. New York: Columbia University Press.

Smith, J.A.; Harré R.; and Van Langenhove L. (1995).Rethinking Methods in Psychology. Thousand Oaks,CA: Sage Publications.

Smith, J.A. (1995). „Semi-Structured Interviewing and Qualitative Analysis« In J..A Smith; R. Harré and L. Van Langenhove: Rethinking Methods in Psychology, 9-26. Thousand Oaks, CA: Sage Publications.

Szebehely, M. (1995). Vardagens organisering. Om vårdbiträden och gamla i hemtjänsten. Lund: Arkiv förlag.

Wilkinson, S. (1988). »The role of reflexivity in feminist psychology."Women's Studies International Forum,.11(5): 493-502. 